\title{
PRZEDMIOTY I PARAMENTY LITURGICZNE PRZECHOWYWANE W ZAKRYSTII KOŚCIOLA MARIACKIEGO W KRAKOWIE W WIEKU XIV i XV
}

Kościół Wniebowzięcia Najświętszej Panny Marii (Mariacki) w Krakowie, niejednokrotnie stanowił obiekt badań historycznych. Wśród starszych opracowań dotyczących krakowskiej fary, niewątpliwie na uwagę zasługują prace Wilhelma Gąsiorowskiego, Zdzisława Bartkiewicza, Edmunda Długopolskiego, Klemensa Bąkowskiego czy Mariana Friedberga, traktujace o fundacji parafii i kościoła, instytucji z nimi związanych, oraz istniejących we wnętrzu świątyni oltarzy ${ }^{1}$. W różnym także stopniu kościół ten został omówiony w przewodnikach dotyczacych Krakowa czy w albumowych wydaniach prezentujących zachowane zabytki w kościele Mariackim ${ }^{2}$. Sporo też publikacji - głównie jednak artykułów - powstało na temat architektury bazyliki Mariackiej (m.in. Józefa Lepiarczyka i Tomasza Węcławowicza) ${ }^{3}$ oraz jej zabytków, które doczekały się nawet osobnych opracowann ${ }^{4}$. Niektóre z zachowa-

${ }^{1}$ W. Gąs i o row ski, Kościót Archiprezbiterialny N.P. Maryi w Krakowie, Kraków 1878; Z. B a r t k i e w i c z, Przyczynek do historii kościoła P. Marii, "Przegląd Powszechny" 1:1891, s. 16-31, 398-406; E. D łu g o pols k i, Katalog kościoła N.P. Maryi w Krakowie, „Teka Grona Konserwatorów Galicyi Zachodniej” 6:1906, s. 1-54; K. B a k o w s k i, Kościól N.P. Maryi w Krakowie, Kraków 1913; M. Friedberg, Zatożenie i początkowe dzieje kościoła N. Panny Maryi w Krakowie (XIII-XV w.), ,Rocznik Krakowski” [cyt. dalej: RK] 22:1928, s. 1-31 (nadbitka).

${ }^{2}$ M.in.: M. Rożek, A. Bujak (zdj.), Kościót Mariacki w Krakowie, Warszawa 1987, J. Samek, Kościót Mariacki w Krakowie, Warszawa 1990; M. R oż e k, A. B u ja k (zdj.), Bazylika Mariacka - Kraków, Kraków 2001.

${ }^{3}$ M.in.: A. S z y z z k - B o hus z, Architektura kościola Najświętszej Panny Marii w Krakowie w historii budownictwa polskiego, Kraków 1913 (Biblioteka Krakowska nr 46); J. L e pi a rczyk, Fazy budowy kościola Mariackiego w Krakowie (wieki XIII-XV), RK 34:1959, z. 3, s. 179-252; T. W ę cł a w o w i c z, Gotyckie bazyliki Krakowa, Kraków 1993; tenże, Droga pielgrzymki droga zbawienia. Mikołaja Wierzynka żal za grzechy na kościele Mariackim przedstawiony, „Peregrinus Cracoviensis” 1:1995, s. 117-134.

${ }^{4}$ Do takich należą m.in. średniowieczne witraże, którym uwage poświęcił już Henryk B r zu ski [w:] Witraże średniowieczne w kościele N.P. Maryi w Krakowie, Kraków 1926 (Biblioteka Historii Sztuki nr 1); w ostatnich czasach jego badania zostały zweryfikowane przez Lecha K a li n ow ski e g o i Helenę M ałk i e w i c z [w:] Średniowieczne witraże kościoła Mariackiego w Krakowie: Dzieje witraży $i$ ich konserwacja, Kraków 1997, s. 13-97 (Studia i Materiały Wydziału Konserwacji i Restauracji Dzieł Sztuki ASP w Krakowie nr 7). Również 
nych zabytków zostały także uwzględnione w dziełach omawiających sztukę Kiakowa czy w ogólnych rozprawach z zakresu malarstwa, rzeźby, rzemiosła artystycznego ${ }^{5}$.

Pomimo jednak tej znacznej ilości opracowań - bezpośrednio, bądź pośrednio odnoszących się do architektonicznego kształtu gotyckiej bazyliki Krakowa oraz współczesnego autorom materiału zabytkowego - niewiele jest wśród nich uwzględniających wyposażenie zakrystii kościoła Panny Marii w XIII-XV wieku. Tymczasem, najstarszy zachowany inwentarz sprzętów liturgicznych przechowywanych w zakrystii kościoła Mariackiego oddaje stan już z końca XIV wieku (1397); również z następnego stulecia przetrwały odnośne spisy ukazujące wyposażenie zakrystii krakowskiej fary. Dokumenty te, pochodzące z XIV i XV wieku, zostały odczytane i opublikowane przez Franciszka Piekosińskiego (m.in. inwentarz z roku 1397, włączony w dokument zezwalający na objęcie urzędu zakrystiana przez Jana Krancza [Kranza, Kranca]) w Kodeksie dyplomatycznym miasta Krakowa ${ }^{5}$ oraz w Najdawniejszych inwentarzach skarbca kościoła N.P. Maryi w Krakowie z XV wieku'. Dotychczas zostały one jednak tylko $w$ niewielkim stopniu wykorzystane w publikacjach uwzględniających średniowieczne wyposażenie kościoła Panny Marii i zasadniczo jedynie na najstarszy inwentarz szerzej powołali się Wilhelm Gąsiorowski, Marian Friedberg i Jerzy Zathey ${ }^{8}$.

Ponieważ inwentarze te, ukazujące bezpośrednio wyposażenie zakrystii kościoła Panny Marii pod koniec XIV i w XV wieku, stanowią w szerszym zakresie cenne źródło do poznania stanu wyposażenia zakrystii kościelnej

inne zachowane w kościele Mariackim zabytki doczekały się szeregu monograficznych opracowań, wśród których niewątpliwie wybijają się ilością rozprawy podejmujące temat twórczości Wita Stwosza. - S. D ett l o ff, Wit Stwosz, t. 1-2, Warszawa 1961. Natomiast podsumowaniem wiedzy o Mariackiej farze i jej zabytkach stało się niewątpliwie, wydane w ramach Katalogu zabytków miasta Krakowa, zbiorowe opracowanie dziejów budowli wraz z jej wyposażeniem. - Katalog zabytków sztuki Krakowa, t. IV: Miasto Kraków, cz. 2: Kościoły i klasztory Śródmieścia, 1, pod red. A. Bochnaka, J. Samka, Warszawa 1971, 1-54.

${ }^{5}$ M.in.: T. D o b r ow olski, Sztuka Krakowa, Kraków $1950^{1}\left(1959^{2}, 1964^{3}, 1971^{4}\right.$, 197855); Kraków, jego dzieje i sztuka, pod. red. J. D o brow olsk i g o, Kraków 1965; J. G a d o m s k i , Gotyckie malarstwo tablicowe Makopolski 1420-1470, Warszawa 1981; tenże, Gotyckie malarstwo tablicowe Matopolski 1460-1500, Warszawa 1988; J. S a m e k, Polskie rzemiosto artystyczne. Sredniowiecze, Kraków 2000.

${ }^{6}$ Kodeks dyplomatyczny miasta Krakowa [cyt. dalej: KDK], cz. 2, wyd. F. P i e k os i ń s k i, Kraków 1882, nr 399, s. 519-522.

${ }^{7}$ Najdawniejsze inwentarze skarbca kościoła N.P. Maryi w Krakowie z XV wieku, wyd. F. Piekosiński, Kraków 1989; przedruk w: „Sprawozdania Komisji do Badań Historii Sztuki w Polsce" 4:1889, z. 2, s. 64-77; Archiwum Państwowe miasta Krakowa [cyt. dalej: APmKr], rkps 3334 b, 1417, 1 sierpnia 1502. Inwentarz skarbca kościoła Panny Maryi, p. 27-68 i 95-100.

${ }^{8}$ W. G ą s i o r ow s k i, Kościót..., s. 59-61; M. F r i e d b e r g, Zatożenie..., s. 19. Natomiast Jerzy Zathey odwołał się do podanego w inwentarzu stanu woluminow przechowywanych w zakrystii kościelnej - zob. J. Z a th ey, Biblioteka kościoła P. Marii w Krakowie na przetomie XIV i XV w. (na marginesie badań nad poczqtkami Biblioteki Uniwersytetu Krakowskiego), „Roczniki Biblioteczne” 8:1964, nr 3-4, s. $19-29$. 
w okresie średniowiecza, wydaje się konieczne ich zestawienie w osobnej publikacji'.

\section{KOŚCIÓ£ PANNY MARII - „MIESZCZAŃSKA” FARA}

Od samego początku istnienia losy kościoła Panny Marii połączyły się z dziejami formującego się na tym terenie zespołu osadniczego, w późniejszym zaś okresie społeczności polokacyjnego Krakowa. Pierwotna świątynia, której budowa rozpoczęła się najprawdopodobniej przed datą przełomu 1221-1222 roku ${ }^{10}$, ukończona została - przynajmniej w najistotniejszej części, jaką był chór - już przed marcem 1224 roku $^{11}$. Wystawiono ją staraniem kształtującego się w tej części zespołu osadniczego, przy niewątpliwym poparciu ówczesnego biskupa krakowskiego Iwona Odrowąża (1218-1229), który też dokonał konsekracji świątyni ${ }^{12}$. Prace nad romańską budowlą zostały jednak najprawdopodobniej przerwane w roku 1241 (w związku z najazdem tatarskim), a do ich kontynuacji przystapiono dopiero pod koniec XIII wieku (1290$-1300)^{13}$. W końcu lat dwudziestych XIV stulecia budowa kościoła Panny Ma-

${ }^{9}$ Inwentarze te zostały również przez autorkę uwzględnione w opracowaniu monograficznym: E. P i w ow a r zy k, Dzieje kościoła Mariackiego (XIII-XVI w.), Kraków 2000, s. $166-180$.

${ }^{10}$ Sprowadzając bowiem do Krakowa zakon Dominikanów (1222), biskup krakowski Iwo Odrowąż (1218-1229) oddał im dotychczasowy kościół parafialny Św. Trójcy, przenosząc jednocześnie znaczną część agend parafii na istniejący już - w lokalizowanej w kierunku północnym od poprzednich osady - kościół Panny Marii. -- [J. D \ u g o s z ], Liber beneficiorum dioecesis Cracoviensis [cyt. dalej LB], t. 3, wyd. A. Przeździecki, Kraków 1864, s. 449; E. P i w o w a r z y k, Dzieje..., s. 27, przyp. 32.

${ }^{11}$ W zapisach z czerwca tegoż roku odnotowano niejakiego Stefana, proboszcza parafii „Sancte Marie de Cracovia" - Kodeks dyplomatyczny katedry krakowskiej ś. Wactawa [cyt. dalej: KKK], t. 1, wyd. F. Piekosiński, Kraków 1874, nr 13 i 14. Adnotacja ta potwierdza równieź pośrednio posiadanie przez kościół Panny Marii praw kościoła parafialnego.

12 Według tradycji przekazanej przez Jana Długosza, fundatorem tej budowli romańskiej, w roku 1222, miał być biskup krakowski Iwo Odroważ. - [J. D ł u g o s z ], Annales seu cronicae incliti Regni Poloniae, t. 3 (lib. IV), przekł. J. Mrukówna, Warszawa 1970, s. 235. Przekaz ten jednak nie jest zbyt wiarygodny, a i sam Długosz nie był mu wierny; nie powtórzył bowiem tej informacji ani w Liber beneficiorum (zob. LB, t. 2, wyd. A. Przeździecki, Kraków 1864, s. 2), ani też w wykazie fundacji przypisanych wspomnianemu biskupowi (zob. [J. D ł u g o s z ], Annales..., s. 255). Podobnie, odrzucić należy teorię opartą na dokumencie źródłowym z roku 1226, stanowiącym rzekomy akt fundacji kościoła Panny Marii przez biskupa krakowskiego Iwona Odroważa. Domniemany oryginał dokumentu erygowania kościoła (1226) i jego transsumpt (1394) pochodzą z dyplomu arcybiskupa gnieźnieńskiego Andrzeja Krzyckiego i biskupa krakowskiego Jana Latalskiego, wydanego w sprawie kazań niemieckich w kościele Mariackim w roku 1536. - Archiwum Parafialne kościoła Mariackiego [cyt. dalej: APkM], dypl. nr 4(11) i 109; KKK, t. 2, wyd. F. Piekosiński, Kraków 1874, nr 398; przedruk: W. G ą s i orow s k i, Kościót..., s. 97-98; Dzieje Krakowa, pod. red. B i en i a z zow n y J., M a ł e ck i e g o J. M., t. 1: J. W y r o z u m s k i, Kraków do schyłku wieków średnich, Kraków 1992, s. 127; Archiwum Kurii Metropolitalnej w Krakowie [cyt. dalej: AKMKr], Acta Visitationis Capituli [AVCap 63], p. 1-1v.

${ }^{13}$ Podjęcie dzieła - bądź też jego kontynuacja - znajduje pośrednie potwierdzenie w dokumencie lokacyjnym wystawionym dla Bronowic Małych w roku 1294. Publikacja dokumentu 
rii była już na tyle posunięta, iż około roku 1320 biskup krakowski Nanker (1320-1326) dokonał konsekracji świątyni ${ }^{14}$. W bezpośrednim związkü z ukończeniem budowy przed rokiem 1327 pozostało zapewne nadanie (pomiędzy rokiem 1327 a 1329) proboszczowi kościoła Mariackiego tytułu archiprezbitera ${ }^{15}$ i utworzenie prepozytury ${ }^{16}$. Nadanie godności archiprezbitera proboszczom parafii Mariackiej - który to tytuł dawał, poza honorowym pierwszeństwem, także prawo zwierzchności nad pozostałymi parafiami Krakowa oraz spełniania funkcji dziekańskich ${ }^{17}$ - wiązało się najprawdopodobniej z rozgraniczeniem parafii krakowskich i wyróżnieniem głównej, jaką była Mariacka. Dokonując takowego rozgraniczenia w roku 1327, dokumentem uwierzytelnionym przez biskupa krakowskiego Jana Grota (1326-1347), wyznaczono m.in. jej zasięg; obejmowała wówczas opieką duszpasterską ludność zamieszkałą wokół Rynku Głównego i Małego, wzdłuż zachodniej strony uli-

[w:] J. P t a śn i k, Studia nad patrycjatem krakowskim wieków średnich [cz. 1], RK 15:1913, s. 93; J. L e p i a r c z y k, Fazy budowy..., s. 193; E. P i w o w a r c z y k, Dzieje..., s. 83.

${ }^{14}$ Co prawda, nie zachował się odnośny dokument, niemniej, poświadczenie tego faktu uzyskujemy drogą analogii opierając się na liście (z 1 X 1321) patriarchy aleksandryjskiego Egidiusza i trzynastu innych biskupów, nadających 40-dniowy odpust dla wiernych odwiedzających kościół Panny Marii w oznaczone uroczystości i święta. - KDK II, nr 370; Z. B a rt k i e w i c z, Przyczynek..., s. 27; M. Fr i e d b e rg, Zalożenie..., s. 12; J. L e p i a r c z y k, Fazy budowy..., s. 194; E. P i w o w a r c z y k, Dzieje..., s. 84-85.

${ }^{15}$ Proboszcza mariackiego z tytułem archiprezbitera, którą to funkcję pełnił wówczas Jan z Głupczyc, odnotowano w dokumencie z roku 1329. - Analecta Vaticana 1202-1366 [cyt. dalej: AVat.], [w:] Monumenta Poloniae Vaticana, t. 3, wyd. J. Ptaśnik, Kraków 1913, nr 247, s. 278. Pojawienie się zapisu świadczącego o istnieniu w kościele Panny Marii tej godności (przy osobie Jana z Głupczyc) jest jedyną notatką potwierdzającą używanie tytułu przez proboszczów krakowskiej fary w tymże stuleciu. Natomiast w roku $1347 \mathrm{w}$ dokumentach zapisano także istnienie tytułu wicearchiprezbitera, które to stanowisko piastował wówczas Jan z Włodzimierza - Acta Camerae Apostolicae, vol. 2, [w:] Monumenta Poloniae Vaticana, t. 1, wyd. J. Ptaśnik, Kraków 1913, s. 36, 45. W XIV wieku archiprezbiterzy świątyni Mariackiej nie mieli jednak większego znaczenia, rzeczywisty zaś zarząd nad kościołem spełniali prepozyci. M. Fri ed b e r g, Zatożenie..., s. 21-22; E. Dłu g o p o ls ki, Katalog.., s. 5-6; E. P i w owa r c z y k, Dzieje..., s. 75 , przyp. $5,7$.

${ }^{16}$ Istnienie urzędu prepozyta, które to stanowisko obejmował wówczas Andrzej de Verulis, zapisano w dokumencie z roku 1330. - KKK II, nr 245, s. 4. Powołanie tej funkcji świadczyłoby być może za zamiarem utworzenia przy świątyni Panny Marii kolegiaty, którego to planu jednak nigdy nie zrealizowano, prepozyturę zaś zniesiono w końcu lat dziewięćdziesiąych XIV stulecia. - E. Dłu g o p o l s k i, Katalog..., s. 5-6; E. P i w ow a r c z y k, Dzieje.., s. 75, przyp. 5,7 .

${ }^{17}$ Zdaniem Mariana Friedberga, za takim ujęciem przemawiałby podział beneficjum kościelnego i stworzenie prepozytury - prepozyt byłby wówczas właściwym proboszczem parafii, archiprezbiter zaś spełniałby funkcje dziekańskie. - M. F r i e d b e r g, Założenie..., s. 21. Istnienie w kościele Panny Marii dwóch urzędów - prepozyta i archiprezbitera - niewątpliwie świadczy o dużym uprzywilejowaniu świątyni, co znajduje również odniesienie do osób piastujących te funkcje w ciagu XIV stulecia. Nie może bowiem ujść uwagi fakt, iż prawie wszyscy spośród nich zostali wysokimi urzędnikami królewskimi, a pięciu nawet biskupami. - Tamże, s. 22-23; B. K u mo r, Dzieje diecezji krakowskiej do roku 1795, t. 2, Kraków 1999, s. 499 i ns., tabela 65 . 
cy Floriańskiej, a po jej wschodniej stronie - od Rynku po ulicę św. Marka (stanowiącą północną granicę parafii) $^{18}$.

Pochodzacy z tzw. drugiej fazy budowy (1290-1320) wczesnogotycki kościół uległ wkrótce dalszym modernizacjom, a prace nad przebudową XIII-wiecznego prezbiterium zapoczątkowano przypuszczalnie już około roku 1340. Jednakże dopiero patronat finansowy (1355-1360) mieszczanina i rajcy krakowskiego Mikołaja Wierzynka Starszego przyczynił się do sfinalizowania dzieła, którego wykończenie detali zostało przerwane około roku $1360^{19}$. Prawie równocześnie $\mathrm{z}$ ukończeniem „wierzynkowego" prezbiterium, około roku 1360 , przystąpiono również do wzniesienia - na miejscu wczesnogotyckiej hali - nowego korpusu halowego (tzw. hali II) ${ }^{20}$. Prace prowadzono zapewne jeszcze w latach osiemdziesiatych XIV stulecia, aczkolwiek $\mathrm{z}$ niewiadomych przyczyn zamiarów zaniechano i w początkach lat dziewięćdziesiątych XIV wieku przystapiono do wzniesienia nowego, bazylikowego korpusu.

Przebudowę rozpoczęto około roku 1392, w roku zaś 1397 nowy, bazylikowy korpus kościoła Panny Marii był już gotowy. Tak szybką realizację projektu umożliwiła znaczna ofiarność mieszczan, którzy już wówczas zaczęli pretendować do roli patronów głównego kościoła parafialnego Krakowa ${ }^{21}$.

${ }^{18}$ Zob. KKK II, nr 374. Komentarz na temat rozgraniczenia parafii krakowskich - m.in.: M. F ri e d b e r g, Założenie..., s. 15; H. Z a r e m s k a, Bractwa w średniowiecznym Krakowie. Studium form społecznego życia religijnego, Wrocław-Warszawa-Kraków-Gdańsk 1977, s. 32-33 ; B. K u m or , Dzieje..., t. 2, s. 490-491. Według badań przeprowadzonych przez Tadeusza Ładogórskiego, dokonanych na podstawie rachunków świętopietrza, przynależnych do parafii Mariackiej przed rokiem 1340 było 7905 wiernych - co w odniesieniu do pozostałych parafialnych kościołów krakowskich określiło ją jako najludniejsza. - T. Ł a d o g ó r s k i, Studia nad zaludnieniem Polski $w$ XIV wieku, Wrocław 1958, s. 196. Natomiast jeszcze przed rokiem 1381 granice parafii Mariackiej zostały nieco uszczuplone, jako ze z jej terenu wydzielono obszar parafii Św. Anny, która objęła wschodnią część miasta, przylegając od północy do parafii Sw. Szczepana - LB II, s. 14; H. Z a r e m s k a, Bractwa..., s. 32, J. Kr a c i k, G. R y ś, Dziesięć wieków diecezji krakowskiej, Kraków 1998, s. 41.

${ }_{19}$ Mikołaj Wierzynek Starszy zmarł bowiem w roku 1360 i wówczas też najprawdopodobniej ustała jego fundacja. O fundacji prezbiterium kościoła Panny Marii przez Mikołaja Wierzynka Starszego - m.in.: J. L e p i a r c z y k, Fazy budowy..., s. 202-205; P. C ro s s le y, Gothic Architecture in the Reign of Kasimir the Great, Krakow 1981, s. 100-103; T. W ę c ł a wo w i c z, Dekoracja figuralna prezbiterium kościola Mariackiego w Krakowie a zagadnienie mecenatu Mikotaja Wierzynka Starszego, RK 56:1990, s. 233-234; tenże, Droga pielgrzymki..., s. 117-134; A. Ko r c z y ń s k a, T. W ę c ław ow i c z, Prezbiterium wierzynkowe. Historia badań i nowe pytania badawcze, [w:] O konserwacji prezbiterium kościoła Mariackiego w Krakowie, pod. red. J. D a r a n ow ski e j- Łuk a s zew sk i e j, Kraków 1998, s. 40; E. P i w o w a r c zy k, Dzieje..., s. 89 i 93, przyp. 57.

${ }^{20} \mathrm{Na}$ temat domniemanej konstrukcji gotyckiej hali (II) kościoła Panny Marii - m.in.: J. L e p i a r zy k, Fazy budowy..., s. 195-207; A. Mił o będ zk i, Późnogotyckie typy sakralne w architekturze ziem polskich, [w:] Późny gotyk. Studia nad sztuka przełomu średniowiecza i czasów nowożytnych, Warszawa 1965, s. 90-91; P. C r o s s l e y, Gothic Architecture..., s. 98-100; E. P i wo w a r c z y k, Dzieje..., s. 94n.

${ }^{21}$ Dostarczenie funduszy na wzniesienie gotyckiej bazyliki znajduje swoje wyraźne potwierdzenie w księgach miejskich $\mathrm{z}$ lat 1392-1397. Budowę poprzedziły jednak wcześniejsze zapisy, odnotowane w rachunkach miejskich, gdzie w latach: 1390, 1391 i 1392 pojawika się nawet osobna rubryka wydatków czynionych ze strony miasta - kwoty te były jednak raczej skromne i wynosiły od 1 do 3 grzywien. - Najstarsze księgi i rachunki miasta Krakowa od 
Ukończenie budowy gotyckiego kościoła Mariackiego zbiegło się bowiem czasowo z podjętymi przcz rajców krakowskich staraniami o przejęcie patronatu nad miejską fara, który przez okres XIII i XIV wieku przysługiwał biskupowi krakowskiemu ${ }^{22}$. Realizując ten kierunek działania, już w latach dziewięćdziesiątych XIV wieku rajcy krakowscy rozpoczęli starania o pozwolenie mianowania przez nich zakrystiana, a w roku 1395 podjęli uchwałą rady miejskiej plan uzyskania patronatu nad farą i wysłali do Rzymu posła ${ }^{23}$. Koncept ten, pomimo poparcia udzielonego przez królową Jadwigę, natrafił na opór rektora świątyni, w konsekwencji czego wszczęto w kurii rzymskiej proces. W roku 1396 udało się jednak rajcom uzyskać od papieża Bonifacego IX pozwolenie na używanie przenośnego ołtarza, na podstawie zaś dwóch innych bulli (z 11 I 1397) otrzymali prawo patronatu nad trzema ołtarzami: Św. Jana Ewangelisty, ŚŚ. Piotra i Pawła, Św. Antoniego, oraz prawo nominowania zakrystiana $^{24}$; ta ostatnia prerogatywa znacznie ograniczyła władze proboszcza, który wniósł apelację do Rzymu. W rezultacie zabiegów zniesiono dotychczasowe stanowisko prepozyta, a ówczesny rektor kościoła - Mikołaj Pieniążek uzyskał (12 X 1402, na mocy bulli Bonifacego IX) uznanie godności archiprezbitera wraz z tytułem infułata, przynależnej odtąd proboszczom kościoła Mariackiego ${ }^{25}$.

r. 1300 do 1400 [cyt. dalej: NKiRMK], wyd. F. P i e k o s i ń s k i i J. S z u j s k i, cz. 2, Kraków 1878 , Distributa, (1390) s. $291,(1391)$ s. 295 , (1392) s. 300 ; wzrosły one nieco w nastepnych latach. Miasto pokryło koszty belek i cegły do posadzki świątyni (1392), zakupiło 4 cetnary ołowiu na pokrycie dachu (zapewne naw bocznych) kościoła (1393) i zapłaciło za kamienie na posadzkę (1394). - Tamże, s. 302 ad 45, s. 306 ad 32 b. Natomiast w roku 1394, mieszczanin krakowski Jan Oderer dokonał zapisu na sklepienie (Cracovia artificum 1300-1500 [cyt. dalej: CA I], wyd. J. P t a śn i k, Kraków 1917 (Źródta do historii sztuki i cywilizacji w Polsce, t. 4), nr 81; Ksiegi tawnicze krakowskie 1365-1376 i 1390-1397 [cyt. dalej: KŁK], wyd. S. Krzyżanowski, Kraków 1904, nr 1676; NKiRMK II, s. 109), a miasto zawarło ugodę z kamieniarzami pracującymi około drugiej części sklepienia kościoła (najprawdopodobniej naw bocznych), mocą której zobowiazało się do wypłacania im tygodniowej stawki płacy (NKiRMK II, s. 3; por. CA I, nr 93). Rok później (1395) w źródłach odnotowano dokonanie kolejnego legatu na sklepienie, a w następnym roku na rzecz kościoła - KLK, nr 2069, 2312. Prace nad wykonaniem sklepienia powierzono w roku 1395 Mikołajowi Wernerowi (CA I, nr 75, 88, 120, 1383 oraz komentarz na s. 28, przyp. 1; NKiRMK II, s. 310 ad 41, s. 317-318 ad 52), który dzieło ukończył w roku 1397. Mniej więcej w tym też czasie założono nad korpusem dachy, a rok później (1398) ukończono malowanie sklepienia nawy głównej (zob. NKiRMK II, s. 310 ad 41, s. 314 ad 41, s. 319, 159, 162). - E. Piwowarczyk, Dzieje.., s. 98, przyp. 78.

${ }^{22}$ Potwierdza to dokument wystawiony w roku 1394, zezwalający na budowę (na terenie cmentarza mariackiego) kościoła Św. Barbary, zastrzegający jednocześnie dotychczasowe prawa katedry krakowskiej względem świątyni Panny Marii. - KDK, t. I, wyd. F. Piekosiński, Kraków 1879 , nr 80.

${ }^{23}$ NKiRMK II, s. 128-129, 253.

${ }^{24} \mathrm{KDK} \mathrm{I}, \mathrm{nr} 85,86$ i 87 . Dzięki tym przywilejom wpływy rajców miejskich na świątynię Mariacką uległy znacznemu zwiększeniu. Dodatkowo, w tym samym roku (1397) miasto przejęło również zarząd nad domem altarystów kościoła (KKK II, nr 425) oraz zyskało wpływ na szkołe parafialna, rozszerzony $w$ roku 1400 o prawo mianowania jej magistra (tamże, $n r$ 291).

${ }^{25}$ APkM, dypl. nr 53(95) i 74(92, 93, 94); druk: KKK II, nr 466. Tytuł archiprezbitera i infułata, nadany ówczesnemu proboszczowi został złączony $z$ urzędem, co stworzyło prawo do jego używania przez każdorazowych następców. Zgodnie z tą prerogatywą każdorazowy rektor 
Nasilone $\mathrm{z}$ końcem XIV stulecia starania rady miejskiej o uzyskanie patronatu nad świątynią Mariacką miał również popierać król Władysław Jagiełło $^{26}$. Takowa protekcja wydaje się jednak dziwna, jako że w stosunkowo niedługim czasie, bo w roku 1415, tenże król zdołał uzyskać dla siebie prawo patronatu nad osiemnastoma kościołami w diecezjach: gnieźnieńskiej, poznańskiej, wrocławskiej i krakowskiej, a w tej ostatniej również i nad kościołem Panny Marii, w którym przysługiwało mu prawo prezentowania kandydata na stanowisko rektora ${ }^{27}$. Na tym tle wyniknął zresztą w nieco późniejszym okresie (1450) konflikt pomiędzy królem Kazimierzem Jagiellończykiem a biskupem krakowskim Zbigniewem Oleśnickim (1423-1455), w związku z nominowaniem przez króla na stanowisko rektora kościoła Jerzego Szwarca; sprawa otarła się o Rzym, gdzie papież Mikołaj V rozstrzygnął ją na korzyść biskupa krakowskiego ${ }^{28}$. Ostatecznie jednak Szwarc utrzymał się na swoim

fary otrzymał prawo używania insygniów biskupich: mitry, pierścienia, pastorału, tuniki i dalmatyki, które to mial nosić w czasie uroczystych błogosławieństw i publicznych procesji zarówno na terenie miasta, jak i poza (o ile nie był obecny specjalny delegat biskupi) oraz prawo wysłuchania spowiedzi $\mathrm{i}$ udzielenia ważnego rozgrzeszenia w zastępstwie biskupa nawet w sprawach dla niego zarezerwowanych. Na temat uprawnień archiprezbitera kościoła Mariackiego oraz problemów związanych z akceptacją tytułu i przywilejów z nim związanych - pisali m.in.: W. Gąs i orowski, Kościót..., s. 66-69; E. Długopolski, Katalog..., s. 9-10; M. F r i e d b e r g, Zatozenie..., s. 20-21, 25-26; E. P i w o w a r c zy k, Dzieje..., s. 77-78.

${ }^{26}$ Stwierdzać miał to rzekomy list, jaki rajcy życzyliby sobie, aby król wysłał do Rzymu, a którego koncept wpisano w Consularia Cracoviensia pod rokiem 1398 - NKiRMK II, s. 186. W liście tym król miał domagać się od papieża, aby uregulował sprawę zarządu kościoła, a przede wszystkim zniósł stanowisko prepozyta łącząc je $z$ archiprezbiterem, prawo zaś kolatorskie, przysługujące papieżowi, przekazał miastu. Tymczasem prepozytura była już przecież ustalona (zob. AVat., nr 212), a prawa patronatu nie wykonywał papież lecz biskup. Tworząc dokument radni chcieli zatem autorytetem papieskim usunąć przeszkodę, jaką stanowił dla ich dążeń - zmierzających do przejęcia fary - biskup krakowski; starania te jednak nie przyniosły rezultatu.

${ }^{27}$ KKK II, nr 557, s. 396.

${ }^{28}$ W roku 1450, Adam z Będkowa, ówczesny archiprezbiter kościoła Mariackiego, zamienił swoją funkcję z Jerzym Szwarcem na kanonię i prebendę w Kielcach, co potwierdził dokumentem z 3 VI 1450 roku (z ramienia prawa prezenty królewskiej) wikariusz generalny krakowski - Zbiór dokumentów katedry i diecezji krakowskiej [cyt. dalej ZDKK], cz. 2, wyd. S. Kuraś, Lublin 1973 (Materiaty do dziejów kościoła w Polsce, t. 4), nr 549 APkM, dypl. nr 34(65); O taki stan rzeczy wszczął jednak z królem spór biskup krakowski Zbigniew Oleśnicki (1423-1455) powołując się na przywilej uzyskany od papieża Mikołaja V z roku 1449, moca którego papież przyznał biskupowi krakowskiemu prawo obsadzania tych beneficjów koscielnych, które by w czasie jego władania diecezją krakowską zawakowały w miesiącach parzystych (tj.: lutym, kwietniu, czerwcu, sierpniu, październiku i grudniu). W wyniku odwolania się do Rzymu, Mikołaj V wydał bullę wyjaśniająca, iż jakkolwiek przysługuje królowi prawo nadania 90-ciu beneficjów kościelnych w polskich prowincjach, bez względu na to w czyjej dyspozycji by się znajdowały, to jednak nie ustępuje to przywilejowi wydanemu dla biskupa krakowskiego w roku 1449. Poddając zaś w wątpliwość prawne objęcie beneficjów przez osoby mianowane przez króla, papież opowiedzial się za prawidłowością nominacji biskupich w miesiącach dla niego zastrzeżonych. - Zbiór dyplomów klasztoru mogilskiego [cyt. dalej: KM], t. 4, wyd. W. K ęt r zy ń s k i, S. S m o l k a, Kraków 1867, nr 1522, s. 507. 
urzędzie, a tym samym Jagiełło potwierdził prawo patronatu, które w odniesieniu do krakowskiej fary sprawowà również Zygmunt $I^{29}$.

Pomimo scedowania prawa patronatu nad świątynią Mariacką (po roku 1415) na króla Władysława Jagiełłę nie wykazywał on jednak, ani jego następcy, większego zainteresowania świątynią. $Z$ takiego stanu byli jednak zadowoleni rajcy krakowscy, którzy de facto przejęli już wcześniej opiekę nad krakowską farą. Ich działalność wyraziła się szczególniej m.in. w funkcji wybieranych dożywotnio (spośród rajców miejskich) prowizorów kościoła. Co prawda początkowo, $\mathrm{w}$ 1. połowie XIV wieku, z ramienia rady miejskiej zbieraniem funduszy na budowę i administrowaniem zapisami na rzecz kościoła zajmował się jeden z rajców, jednak już po roku 1370 administrację funduszy kościelnych przejęło dwóch prowizorów; stan ten utrzymał się także przez następne stulecie. Prowizorowie mieli w swoim zarządzie kilka sum na restaurację świątyni, rozporządzali funduszami na potrzeby wewnętrzne oraz wykonywali nadzór nad zakrystia, prowadząc regestr dochodów i wydatków kościelnych $^{30}$.

Uprawnienia rady miejskiej wobec fary zostały jeszcze rozszerzone w roku 1396, kiedy to rada uzyskała prawo do nominowania na urząd zakrystiana, który w okresie średniowiecza był jednym $\mathrm{z}$ istotniejszych urzędów kościelnych, a w kościele Mariackim - ze względu na zakres swojego działania najważniejszym po archiprezbiterze. Prezentowany przez radę miejską na stanowisko zakrystiana duchowny nadal podległy był jednak kontroli biskupa krakowskiego i na jego żądanie składał sprawozdanie ze stanu zakrystii ${ }^{31}$. Opierając się na wspomnianym przywileju papieskim, po raz pierwszy rada miejska zamianowała w roku 1397 na stanowisko zakrystiana „swojego" duchownego - Jana Krancza [Kranza, Kranca] ${ }^{32}$; wówczas też dokonano spisu przedmiotów i paramentów liturgicznych (pierwszego potwierdzonego dokumentem) przechowywanych w zakrystii ${ }^{33}$.

Opisany w bulli papieskiej Bonifacego IX zakres obowiązków zakrystiana w kościele Panny Marii, koncentrujący się głównie wokół troski, by zasoby zakrystii - będące w dużej części wyrazem ofiarności mieszczan krakowskich - nie uległy rozproszeniu i sprzedaniu, wraz ze zwiększającymi się ilościowo w ciągu wieków przedmiotami i paramentami liturgicznymi stopniowo

${ }^{29} \mathrm{~W}$ dyplomie wydanym na sejmie walnym w Krakowie, w roku 1537 Zygmunt I wyraźnie zaznaczył: „Ecclesiae s. Mariae Cracoviensis iuris patronatus nostris”. - Prawa, przywileje i statuta miasta Krakowa [cyt. dalej: PPSMK], t. 1, wyd. F. Pi e k o s ińs k i i S. K rzy ż a n ow ski, Kraków 1885, nr 755.

${ }^{30}$ E. D tug op olski, Katalog..., s. 2-3.

${ }^{31} \mathrm{KDK}$ I, nr 87. Bullę Bonifacego IX zatwierdził i transsumował w roku 1406 papież Innocenty VII, zaznaczając wyraźnie, iż rajcy krakowscy zamianowali zakrystiana. - Tamże, nr 109.

32 Jan Krancz [Kranz, Kranc] pochodzil z krakowskiej rodziny Kranczów; tytuł bakałarza wydziału artium uzyskał $w$ roku 1383 w Pradze. - J. Z a t h e y, Biblioteka..., s. 21. Zatwierdzenia Jana Krancza na stanowisku zakrystiana dokonał biskup krakowski Piotr Wysz (1392-1412).

${ }^{33}$ KDK II, nr 399. 
wzrósł jeszcze w znaczenie. $Z$ czasem z urzędem zakrystiana złączono też szereg zapisów, z których czynsze szły albo na utrzymanie zakrystiana, albo też dysponował on nimi na potrzeby zakrystii (m.in. zakup wosku czy wina); na jego ręce składano także opłaty za „dzwonne" czy „od grobów”, rozdzielane według ustalonej zasady. Ten zwiększający się zakres działalności zakrystiana kościoła Mariackiego stał się zapewne przyczyną utworzenia w późniejszym okresie pomocniczego urzędu - podzakrystiana; nie potrafimy jednak określić bliżej kiedy funkcja ta została ustanowiona (z pewnością istniała już w XV wieku), ani też sprecyzować zakresu związanej z nią posługi ${ }^{34}$. Natomiast pod koniec następnego stulecia - zgodnie $\mathrm{z}$ ordynacją kardynała Jerzego Radziwiłła (1598) - zarówno prawo prezentowania (za poprzednim porozumieniem się co do osób z każdorazowym archiprezbiterem) na stanowisko zakrystiana, jak i podzakrystiana należało do rajców krakowskich. Na mocy wspomnianego dokumentu rajcy otrzymali też prawo do wyboru i prezenty (pod takim samym warunkiem, jak na poprzednie urzędy) na stanowisko kaznodziei, organisty, rektora szkoły i kantora ${ }^{35}$.

W ten sposób, przejmowany przez miasto już od lat dziewięćdziesiątych XIV wieku patronat nad krakowską fara, otrzymał swoje ugruntowanie również w następnych wiekach. Szczególnym zaś tego wyrazem stało się uzyskanie przez radę miasta prawa do mianowania na urząd zakrystiana. Dzięki tej prerogatywie zachowały się - skrupulatnie spisywane przez przedstawicieli miasta przy zmianie na stanowisku zakrystiana - inwentarze, na podstawie których możemy odtworzyć wyposażenie w sprzęt i paramenty liturgiczne (stanowiące $\mathrm{w}$ większości dary krakowskich mieszczan) zakrystii kościoła Panny Marii w XIV-XV wieku.

\section{WYPOSAŻENIE ZAKRYSTII KOŚCIOLA PANNY MARII}

Pierwszego (najstarszego $\mathrm{z}$ potwierdzonych odnośnym dokumentem) spisu przedmiotów i paramentów liturgicznych przechowywanych w zakrystii kościoła Panny Marii dokonano w roku 1397, przy okazji objęcia urzędu zakrystiana przez wspomnianego już Jana Krancza [Kranza, Kranca] ${ }^{36}$. Według sporządzonego wówczas inwentarza, znajdowała się tam jedna pozłacana monstrancja, ofiarowana przez obywateli krakowskich, oraz - służąca do przechowywania Najświętszego Sakramentu - skrzyneczka ozdobiona miedzianymi, pozłacanymi taśmami, darowana przez zakrystiana Jana (zapewne Krancza). Do sprawowania Najświętszej Ofiary służyć mogło aż siedemnaście kielichów z patenami, z których dwanaście było pozłacanych, sześć zaś srebr-

${ }^{34}$ APkM, księga nr 21, p. 18. Do czynności podzakrystiana należało prawdopodobnie m.in.: czuwanie nad porządkiem w zakrystii, dbanie o czystość aparatów kościelnych i paramentów liturgicznych, jak i wspólne z zakrystianem dokonywanie zakupu wosku i wina. E. D t u go p ols k i, Katalog..., s. 14-15.

${ }^{35}$ APkM, ks. nr 21, k. 18.

${ }^{36}$ KDK II, nr 399. Zob. też: W. Gą s i o r ow ski, Kościót.., s. 59-61; M. F ri e d b e r g, Zatożenie..., s. 19; E. P i w o w a r c z y k, Dzieje..., s. 166 i ns. 
nych; jeden z pozłacanych kielichów stanowił dar obywatela krakowskiego Walkera. Darem mieszczan krakowskich był także wielki, poziacany krzyż oraz cztery srebrne, relikwiarzowe monstrancje $\mathrm{i}$ - ofiarowany przez niejaka wdowę Katarzynę - mały, srebrny i pozłacany krzyż relikwiarzowy, mający w środku kamień szlachetny beryl i relikwie. W zakrystii kościelnej przechowywano też cenny - niewatpliwie z racji ofiarodawcy - dar królowej Jadwigi, jakim był obraz Matki Bożej zdobiony (najprawdopodobniej na ramie) „gemmis et preciosis lapidibus" ${ }^{\$ 37}$. Idąc z posługą do chorych, kapłani mogli korzystać $\mathrm{z}$ dwóch srebrnych, pozłacanych puszek, sprawionych przez mieszczan krakowskich. Na stanie zakrystii znajdowały się także cztery ampułki, z których dwie były srebrne, a dwie pozłacane, oraz srebrna, pozłacana kadzielnica, będąca darem krakowskich mieszczan. $Z$ dodatkowych przedmiotów przechowywano: dwa srebrne kandelabry (stanowiące dar obywateli Krakowa), cztery cynowe lichtarze (ofiarowane przez witryków kościoła) oraz dwa posrebrzane krzyże do choragwi (ufundowane przez wspomnianego już Walkera).

Prócz powyżej zestawionego wyposażenia w przedmioty liturgiczne, w zakrystii znajdowała się również spora liczba paramentów liturgicznych w postaci ornatów, dalmatyk, alb, obrusów, zasłon do oltarzy itp., stanowiących w większości dary mieszczan krakowskich. Wśród owych paramentów niewątpliwie cennymi był jeden ornat $\mathrm{i}$ dwie dalmatyki oraz obrus na oltarz (,omnia rubea de camcha") i zasłona - „,cortena siue tectura" zapewne antependium) do wielkiego ottarza, ofiarowane przez królową Jadwigę. Dwa inne ornaty, jeden w kolorze czerwonym (,subducta purpura”, „satis bona auro et serico intexta") oraz drugi "de blance attlassone et vna textura insignita", a także świąteczne antependium do ołtarza głównego, sprawione zostały ze wspólnych składek obywateli miasta. Kolejne dwa białe ornaty ofiarowali też: jeden ( $\mathrm{z}$ kamchy) - Jan Gerlaci, a drugi ( $\mathrm{z}$ atłasu) - Jan z Kozłowa, altarysta w kościele Mariackim; ornat zielony (z aksamitu) sprawił Michał, niegdysiejszy zakrystian kościoła. Prócz wspomnianych ornatów przechowywano w zakrystii również siedemnaście innych, określonych jako „świąteczne”, oraz dwanaście „codziennych”, trzy dalmatyki i osiem kap (w tym jedna atłasowa). Natomiast do zasłaniania mensy ołtarzowej ołtarza głównego służyło (oprócz wspomnianego już daru Jadwigi) jeszcze pięć innych obrusów, do innych zaś ołtarzy - dwadzieścia cztery.

${ }^{37}$ Obraz ten odnotowany został również w następnych inwentarzach spisanych $w$ XV wieku, w których wymieniono: w roku 1417 - ,ymago beate uirginis iammis decorata", a w roku 1452 - „tabula maior beate Virginis argento deaurato superducta”. - Najdawniejsze inwentarze..., s. 7, 21. Natomiast w inwentarzu z roku 1584, w spisie zatytułowanym Naczynia do obrzędów świętych, zapisano: „Obraz Panny Maryi srebrem oprawiony na około, na którym są herby królestwa węgierskiego i polskiego, na piersiach kamień wielki szafir, perłami osadzony. Jednak na tym obrazie wiele pereł i różyczek niedostaje." - A. G r a bow sk i, Skarbniczka naszej archeologii, Lipsk 1854, s. 158. Zdaniem Jerzego Gadomskiego, wszystkie trzy powyższe zapisy odnoszą się do obrazu ofiarowanego przez królową Jadwigę do kościoła Panny Marii. - J. G a do m sk i, Gotyckie malarstwo tablicowe Małopolski 1460-1500, s. 24; [E. Now a kow ski] Wacław z Sulgostowa, $O$ cudownych obrazach w Polsce Przenajświętszej Matki Bożej. Wiadomości historyczne, bibliograficzne i ikonograficzne, Kraków 1902, s. 322. 
W roku 1397, w zakrystii kościoła Mariackiego znajdowały się także księgi potrzebne do sprawowania nabożeństw, jak: mszały (9), graduały (3), antyfonarze (2), psałterze (5), ale i trzytomowa Biblia, Dialogi Grzegorza Wielkiego czy zapisane na pergaminie Rubryki kościoła krakowskiego - stanowiące razem trzydzieści siedem dzieł w czterdziestu woluminach ${ }^{38}$.

Odnotowany zatem, pod koniec XIV wieku, stan wyposażenia zakrystii kościoła Panny Marii przedstawiał już sporą liczbę różnego rodzaju przedmiotów i paramentów liturgicznych. Zdecydowana większość z nich stanowiła wyraz ofiarności mieszczan krakowskich, którzy fundowali je bądź pojedynczym aktem, bądź też wspólnymi wysiłkami, co potwierdzało jednocześnie coraz bardziej uwidaczniające się znaczenie świątyni dla krakowskiego patrycjatu. Ofiarowany zaś przez królową Jadwige obraz, ornat, dwie dalmatyki i dwa obrusy stanowiły niewatpliwy wyraz pewnego rodzaju poparcia, jakiego udzielała królowa wzrastającemu w znaczenie kościołowi. To XIV-wieczne wyposażenie zakrystii świątyni Mariackiej było również sukcesywnie powiększane w ciągu następnego stulecia poprzez kolejne fundacje mieszczańskie, a jego wzrost poświadczają zachowane $\mathrm{z} X V$ wieku inwentarze zakrystii ${ }^{39}$.

Pierwszy XV-wieczny zapis, ukazujący stan wyposażenia zakrystii kościoła Panny Marii, wykonano około roku 1417 i już wówczas widoczne stały się zmiany w przechowywanym tam sprzęcie. Według tegoż inwentarza, do wystawiania Najświętszego Sakramentu nadal służyła ta sama pozłacana monstrancja, którą - jak dowiadujemy się z ówczesnego zapisu - ozdabiały dwa pozłacane anioły; przybyła jednak jeszcze jedna pozłacana monstrancja dla codziennego wystawiania Najświętszego Sakramentu oraz pozłacana puszka na hostię i dwie srebrne puszki do przenoszenia wiatyku. Zwiększyła się również liczba kielichów, jako że odnotowano jeszcze dwa pozłacane oraz trzy srebrne $^{40}$, a także ilość relikwiarzy o: duży, posrebrzany krzyż z umieszczonymi na jego odwrocie relikwiami, dwie miedziane, pozłacane puszki (w jednej z nich znajdowały się relikwie św. Maurycego), srebrny krzyż z relikwiami oraz trzy inne relikwiarze, w tym jeden z relikwiami Jedenastu Tysięcy Dziewic. Przybyło także ornatów, których odnotowano już dwadzieścia ,świątecznych" oraz dwanaście „zwykłych”, a do tego kapłani mogli również korzystać z pięciu dalmatyk i czterech kap. Znacznie wzrosła też liczba - przechowywanych w sali bibliotecznej (przy zakrystii) - ksiąg liturgicznych, wśród których było m.in. dwanaście mszałów (w tym osiem dużych i cztery małe); do tego doszły kolejne woluminy traktatów teologicznych czy filozoficznych, tak że około roku 1417 biblioteka osiagnęła już stan sześćdziesięciu pięciu dzieł w ponad osiemdziesięciu woluminach (!). Jeszcze w czasie spisywania wspo-

${ }^{38} \mathrm{KDK}$ II, nr 399, s. 521. Księgi te wykorzystywane były nie tylko przez kapłanów obsługujących świątynie, ale również - jak starał się tego dowieśc Jerzy Zathey - w działającej przy kościele Panny Marii szkole parafialnej. - J. Z a th e y, Biblioteka..., passim.

${ }^{39}$ Najdawniejsze inwentarze..., passim; przedruk z: „Sprawozdania Komisji do Badań Historii Sztuki w Polsce" 4:1889, z. 2, s. 64 i ns.

${ }^{40}$ Jeden z kielichów oraz ornat sprawił do kościoła jeszcze w roku 1409 Dythmar [Dytmar, Ditmar]. - CA I, nr 175. 
mnianego inwentarza napłynęły kolejne dary w postaci żółtego ornatu z kamchy, ofiarowanego przez magistra Mikołaja Goltberga [Colbarga, Golbarga, Gothbarga], oraz kodeks Summa Raymundi glosata, przekazany przez jakiegoś studenta $^{41}$.

Następne paramenty oddane do krakowskiej fary odnotowano już w roku 1419, wśród nich zaś znalazły się: srebrny kielich z pateną (dany przez pana Andrzeja), srebrny kielich i ornat „de auro in rubea baldka" (dar pana Rolle), oraz trzy inne pozłacane kielichy z patenami; srebrny pozłacany krzyż, "quam diu vitam duxerit in humanis" (dany przez zakrystiana Mikołaja); adamaszkowy ornat i humerał (dar Jana Lidentolde [Linttoldusa, Linttholdusa, Littoldusa]), dwa czerwone ornaty $\mathrm{z}$ tafty i kamchy (ofiarowane przez Stoberinne [Stoberowa]), bliżej nieokreślony ornat (dar niejakiej Geyslerinne [Geislerowej]), ornat $z$ kamchy $i$ adamaszku (dany przez Schorembranta [Schorenbrantha]), ornat $\mathrm{z}$ aksamitu (z zapisu Mikołaja Geyskonis [Geiskonis]), dwie dalmatyki z kamchy oraz pięć humerałów $\mathrm{w}$ tym jeden $\mathrm{z}$ bursa, poduszka z żółtego aksamitu (zapewne do krzesła biskupiego) oraz trzy nowe księgit ${ }^{\mathbf{4}}$. Natomiast w roku 1424 sprawiono także przenośny ołtarz z alabastru, ozdobiony pozłacanym srebrem, który przechowywany był tymczasowo w ratuszu miejskim $^{43}$.

W trzy lata później (1427) powiększeniu uległy nie tylko zasoby biblioteki wzbogacone o osiem nowych woluminów, ale i zakrystii, do której oddano pięć kielichów (jeden ofiarował proboszcz Adam z Będkowa) oraz pięć ornatów - w tym jeden $\mathrm{z}$ daru samego króla Władysława Jagiełły ${ }^{44}$, inny zaś - Mikołaja Kyzewetera. W następnym roku (1428) sprawiono do świątyni jeszcze jeden srebrny kielich z patena, a magister Mikołaj Goltberg [Golbarg, Gothbarg, Colbarg] zapisał dwadzieścia woluminów ksią ${ }^{45}$.

Natomiast już w roku 1438 zarząd miasta oddał z przechowywanych w zakrystii kościoła przedmiotów liturgicznych „starą”, większą monstrancję, cztery małe monstrancje (prawdopodobnie relikwiarzowe) oraz dwa srebrne kielichy do warsztatu złotniczego Brennerów celem sprawienia do świątyni nowej monstrancji ${ }^{46}$. Być może, iż decyzja złożenia zamówienia w warsztacie

${ }^{41}$ Najdawniejsze inwentarze..., s. 7 i ns.

${ }^{42}$ Tamże, s. 11-12. W roku 1419 odnotowano również dar w postaci ,parva tabula aurea de latitudine et longitudine trium digitiorum, quadrata" (Tamże, s. 12).

${ }^{43}$ Dar ten zapisano: „Datus est vnus lapis altare portatile de alabastro inclusus et ab infra totus tectus argento deaurato (...); si non liberabitur pro IX marcis, pro quibus pignus est, exnunc ipsi ecclesie beate virginis Cracouiensis". - Najdawniejsze inwentarze..., s. 12.

${ }^{44}$ Ofiarowanie ornatu do kościoła Panny Marii przez króla Władysława Jagiełłę podał Franciszek P i e k os i ń ski (Najdawniejsze inwentarze..., s. 5), a za nim przytoczył również Marian Fri e d b erg. (Założenie..., s. 27).

${ }^{45}$ Najdawniejsze inwentarze..., s. $12 \mathrm{n}$.

${ }^{46} \mathrm{CA}$ I, nr 331. Starą monstrancję na przerobienie przyjął Paweł Brenner, a pozostałe przedmioty Michał Brenner. Zdaje się jednak, iż zlecenia wykonania nowej monstrancji podjął się Paweł Brenner, który zamierzonego dzieła nie skończyl, po nim zaś przejął je, zaślubiony z wdowa po Pawle, niejaki Mikołaj (prawdopodobnie również Brenner) z Paczkowa. - Tamże, Addenda, nr 1384; B. P r z y b y s z e w s k i, Złoty dom królestwa. Studium z dziejów krakow- 
Michała Brennera opierała się na znajomości jego dzieł, jakimi były kielich (z ok. 1438?) z napisem: AVE VERUM CORPUS CHRISTI NATUM EX MARIA VIRGINE VERE oraz krzyż ołtarzowy ${ }^{47}$. Nową monstrancję do Mariackiej świątyni wykonano około roku $1441 \mathrm{w}$ warsztacie Brennera, kierowanym wówczas przez Mikołaja Brennera z Paczkowa, a jej istnienie odnotowano w przeprowadzonym w roku 1452 inwentarzu, gdzie zapisano: „monstrancia magna (cum alia magna) ${ }^{9,48}$.

W następnych latach ilościowy stan przedmiotów i paramentów liturgicznych uległ dalszemu powiększeniu, a w przeprowadzonym w roku 1449 inwentarzu sprawionych do kościoła Panny Marii szat liturgicznych odnotowano otrzymanych aż trzynaście nowych, „światecznych” ornatów, z których prawie każdy miał odpowiedni humerał, oraz dwie dalmatyki i jedną kapę ${ }^{49}$.

Kolejny zachowany inwentarz zasobów zakrystii kościoła Mariackiego sporządził w roku 1452 Mikołaj Knoll, notariusz miejski. Zapisał w nim posiadanie przez farę trzech monstrancji, $\mathrm{z}$ których jedna była duża (pochodząca z warsztatu Michała Brennera), druga - pozłacana (używana była w procesji Wielkanocnej), trzecia zaś - również pozłacana - miała kształt wieżyczkowy, a w środkowej części (na umieszczoną w niej hostię) okrągły. Przy okazji nabożeństw sprawowanych przed ołtarzem głównym wynoszony był zapewne (znajdujący się na co dzień w zakrystii) duży, pozłacany krzyż, ozdobiony szlachetnymi kamieniami. Prócz niego przechowywano tam jeszcze inny srebrny krzyż, częściowo złocony, ze srebrną stopą (zapewne ołtarzowy), ozdobiony jedenastoma kamieniami (z których cztery były duże, a pięć średnich), oraz dwa małe, srebrne, pozłacane krzyże ołtarzowe; nadal były też dwa krzyże do choragwi. Sprawując Najświętszą Ofiarę, kapłani mogli korzystać

skiego cechu ztotniczego od czasu jego powstania (ok. 1370) do potowy wieku XV, Warszawa 1968 , s. 87,90 .

${ }^{47}$ Istnienie kielicha $\mathrm{z}$ napisem: AVE VERUM CORPUS CHRISTI NATUM EX MARIA VIRGINE VERE zapisano w inwentarzu z roku 1452: „Eyner am fus mit bildwerg, dy heupte vnd antlicz forne sint nicht obirgolt, oben an mit bloer vnd grüner floriture vnd eyn umbschrift «Aue verum corpus», der knof mit czynnen vnd gefenstirt" (Najdawniejsze inwentarze..., s. 22). Kielich ten, podobnie jak i wspomniany krzyż ołtarzowy, są jedynymi z przetrwałych do czasów obecnych przedmiotami liturgicznymi z 1. połowy XV wieku, znajdującymi się obecnie na stanie wyposażenia skarbca kościoła Mariackiego. Wspomniany kielich oraz krzyż ołtarzowy opisuja m.in.: A. E s s e nw e in, Die Mittelalterlichen Kunstdenkmale der Stadt Krakau, Leipzig 1869, s. 162-163; M. i S. C e r c h o w i e, F. Ko p e r a, Pomniki Krakowa, t. 1, KrakówWarszawa 1904, s. 150-151; A. B o c h n a k, J. P a g a c z e w s k i, Polskie rzemiosto artystyczne wieków średnich, Kraków 1959, s. 73-74, 80; B. P r z y b y s z e w s k i, Zloty dom..., s. 82 i ns.; J. S a m e k, Polskie ztotnictwo, Kraków 1988, s. 33-34; tenże, Polskie rzemiosto..., s. 80-81; tenże, Skarbiec kościoła Mariackiego w Krakowie, Kraków 2000 (rękopis w posiadaniu autora), s. 13 n.; kielich jest wzmiankowany również przez: Katalog zabytków..., s. 36, 40; Z. P i e c h, Corpus inscriptionum Poloniae, t. 8: Województwo krakowskie, pod red. Z. Perzanowskiego, z. 2: Bazylika Mariacka w Krakowie, Kraków 1987, nr 7, s. 85; J. Samek, Kościót Mariacki..., s. 29; E. P i w o w a r c z y k, Dzieje..., s. 170-171.

${ }^{48}$ Najdawniejsze inwentarze..., s. 20. Na temat warsztatu złotniczego Brennerów działającego w 1. połowie XV wieku pisali: B. P r z y b y z z ew s ki, Ztoty dom..., s. 79 i ns., 90 i ns.; J. S a m e k, Polskie ztotnictwo, s. 34-35; tenże, Polskie rzemiosto.., s. 82.

${ }^{49}$ Najdawniejsze inwentarze..., s. 14-15. 
z trzydziestu trzech pozłacanych kielichów, w tym z ośmiu srebrnych mających pozłacaną tylko czarę oraz dwóch srebrnych ampułek i dwóch srebrnych kadzielnic $^{50}$.

W początkach 2. połowy XV wieku znajdowała się również w zasobach zakrystii stosunkowo duża liczba relikwiarzy o różnych kształtach, wśród nich zaś m.in.: podłużna skrzyneczka miedziana, pozłacana (z relikwiami św. Maurycego i Towarzyszy); obraz przedstawiający Wniebowzięcie NMP w ramie, w której za szybami znajdowały się relikwie; skrzyneczka z kości (z relikwiami św. Innocentego); biały ( $z$ alabastru? srebra?) krzyż ze srebrną postacia Ukrzyżowanego i z relikwiami; cztery monstrancje relikwiarzowe, w tym jedna $\mathrm{z}$ relikwiami śś. Kosmy i Damiana, druga (wieżyczkowa) - z relikwią kości św. Maurycego i Towarzyszy, trzecia $-\mathbf{z}$ relikwiami w reservaculum $(z$ daru Crakera [Krakera]), czwarta (starsza) - z berylem i relikwiami; oraz srebrna pozłacana głowa (herma?). W inwentarzu wyliczono także - należący do kościoła, lecz wypożyczony radzie miejskiej - zamykany, drewniany obraz z pozłacanym wnętrzem i $z$ relikwiami (umieszczonymi zapewne $w$ ramie). Oprócz powyższych przedmiotów liturgicznych, w zakrystii przechowywano także srebrnego „Baranka Bożego” (ofiarowanego przez zmarłego dzwonnika Mikołaja), puszkę na hostię (sprawioną przez rajców miejskich) oraz dwa srebrne lichtarze. Natomiast wśród paramentów liturgicznych odnotowano $\mathrm{w}$ inwentarzu aż pięćdziesiąt pięć różnorodnych ornatów z ozdobnymi hume-

${ }^{50} \mathrm{~W}$ inwentarzu zakrystii kościoła Mariackiego, z roku 1452, odnotowano dwadzieścia cztery kielichy pozłacane, wśród których znajdowały się: „Primo der grosse kelch obirgolt, do man das heiligtum innetregt. Der ander vdnen am fus mit bildwerg dirhaben vnd getornit am knofe; Hunc comparauerunt domini Craker et Iohannes. Item eyner mit aufgegrabenen bilden am fus, am obirteil mit gesmelczten lilien, der knof auch getörnit. Eyner am fus mit bildwerg, dy heupte vnd antlicz forne sint nicht obirgolt, oben an mit bloer vnd grüner floriture vnd eyn umbschrift «Aue verum corpus», der knof mit czynnen vnd gefenstirt. Eyner, der hot keyne floriture am fusse, sunder oben ist eyn vmbschrift: «Hunc calicem comparauit dominus Iohannes Pauli», dorunder sint angelegt dirhabene blumen. Eyner mit eynem breiten orificio, am fusse mit gebogenen ausgeslagen blumen, obir vnd vndir dem knoffe ouch cleyn geblumet. Eyner mit zechs irhabenen blumen am fusse, am knoffe ist eyn gesmelczt «lhc n. r. j. »., Eyner mit vir ewangelisten am fusse vnd dorczu eyn vmbschrift «Hunc calicem comparauit domina Elisabeth». Eyner mit eynem crucifixo, am fusse circumscripcio: "Calix Iohannis de Wislicia». Eyner mit ausgegrabenen ewangelisten vnd cum Misericordia, der knof ist geeckt. Eyner slecht am fusse geeckt mit eynem sulchen czeichen (...). Eyner am fusse cum crucifixo, of eyner zeiten mit eynem czeichen, of der ander «Anna» buchstaben. Eyner slecht, am fus cum solo crucifixo. Eyner am fus cum crucifixo et post tergum cum tali signo (...). Drey mit slechtin keulichten knoffen, forma ipsorum simplex est et parua, sed sunt ponderosi. (Eyner ist genomen zu der monstracien ad lignum vite, vnd also ist noch czwe). Eyner slecht ausgeslagen am fus, der knof ist gepockilt. Eyner am knoffe ist slecht eckwerg, an iczlicher ecke eyn buchstabe «Maria». (...) eyner mit gesmelcze, der knof mit czynnen, habet clipeum in pede, hunc dedit Lucas Waltdorf. Item Wenczelynne monetaria dedit vnum calicem (...) eyn newer kelch cum clenodio ciuitatis in pede. Item dominus Martinus cantor, vicarius ecclesie habet calicem, ille debet esse ecclesie. (Item calix deauratus donatus ecclesie per Katherinam Klosz Graserinne, subtus pede scriptum est: "Closze Glaser vnd Katherina»" (Najdawniejsze inwentarze..., s. 22-23). Był tam również jeden kielich - ozdobiony napisem na czarze: „Aue Maria gracia plena etc. et in parte pedis simplex effigies Misericordie Domini" - z pateną które zostały legowane przez polskiego kaznodzieje w kościele Panny Marii. - Tamże, s. 23. 
rałami, sześć dalmatyk, dziesięć kap oraz osiem serwet na ołtarz, jedno duże antependium „cum leone et puluinar" $\mathrm{z}$ żółtego aksamitu i jeden welon, „quod in summis festiuis superducitur super altari" ${ }^{51}$. Zdecydowanie bogato przedstawiały się również w początkach 2 . połowy XV wieku zasoby biblioteki Mariackiej; w roku 1452 zbiory liczyły już sto trzydzieści (!) dzieł, w tym również księgi pisane na pergaminie ${ }^{52}$.

${ }^{51}$ Wśród wymienionych przez inwentarz z roku 1452 ornatów znalazły się m.in.: „Primo ornatus. Czum irsten dy beste sammitte kazil, der bodem des meyste von golde mit rozen ingetragen, mit cleynne grunne bleterleyn, mit eynem creucze gar von perlen (...). 2us. Dy andir mit golden fogilchen vnd grünem blumwerg, das creucze ist mit perlen adlern (...). 3us. Item eyn weisser ornat von damaschken mit eynem perlen creucze (...). 4us. Item eyn roter atlissyn ornat von golde, quem dedit Wenczelynne monetaria, non habet crucem (...). 5us. Item eyn alder gehafter ornat, das creucze ouch gehaft mit tirchen, blumwerg vnd bildwerg mit golde et est festiuus quondam solennis (...). 6. Item eyn bloer ornat von sammet mit bloen rozen, der rozen kern ist weis, das creucze gehaft, dy diademata doryn sint mit perlen (...). 7us. Item eyn bloer ornat von atlas mit weissen fögiln of goldenen czweiglen, mit eynem gehaften creucze (...). 8us. Item eyn roter damaschken ornat mit eynem grosen gehaften creucze, olim domini Craker (...). Nonus. Item eyn blo atlissyn ornat mit eynem golden breiten gehaften creucze (...). Xus. Item eyn lichtblo koftiryn ornat cleyn gebilt olim Abrahe, cum cruce, cuius passio [domini est de perlis et diademata imaginum]-eque de perlis (...). XI. Item ornatus olim Kerber, eyn rote balke cum magnis aureis auibus et canibus, sub canibus tortura czedilwerg (...). XII. Item abir eyn sulch rot balke mit goldener floritur, mitfrawen ader gesellen im ioguntborn, subductus viridi charas (...). XIII. Item eyn blo balke mit goldenen blumwerg, eyn iczliche sam in seyner geheuze (...). XIIII. Item eyn ornat etwen Wenczelynne monetarie eyn gele kamche, bowmwerg ader blumwerg mit golde ingesprengt, das creucze ist von blumwerg mit perlen (...). XV. Item eyn blo atlis ornat mit golden fogiln of roten vnd bloen czweigen, das creucze gehaft mit halben bildern Marie (...). XVI. Item eyn blo koftiren omat, crux de pretexta lata aurea (...). XVII. Item eyn geferbter brawner koftiryn ornat, von eynem golden borten das creucze (...). XVIII. Item eyn ornat von brawnem sammet, das creucze eyn goltborte vmbczogen mit eynem andirn cleynen börtchen (...). XIX. Item eyn swarcz brawn sammet ornat mit eynem golden gehaften creucze, ouch vmczogen mit eynem andirn cleynen börtchen golden (...). XXus. Item eyn camchen ornat des alden sacristiani Nicolai, mit blumwerg vnd streyffen, dorynne grüne rozen vnd süst ingesprengt mit lichtblo. Crux slecht gehaft (...). XXIus. Eyn camchen ornat, rotblumwerg im swarczen. Crux antiqua de auro et floribus oblongis cum viridi et rubeo, cum imagine beate Virginis ofgedrugt (...). XXIIus. Eyn ornat von gefogilter camche, der grunt blo, floritura est de viridi, dorynne blumen, tirchen, fögilchen rot, weis (...) XXIIIus. Eyn ornat von slechtem grünem sammet ane bildung pro missis Corporis Christi (...). XXIIIIus. Eyn ornat von grüner koftir. Crux eyn heidenisch borte de auro pro missis Corporis Cristi (...). XXVus. Eyn grün kamchen ornat, parua pretexta est crux (...) Fuit domini Czanser. XXVI. Eyn rot kamchen ornat mit gelen fogiln. Crux swarcz mit gehaftem blumwerg (...). XXVII. Eyn falrot ornat koftiren, crux pretexta alba argentea (...). XXVIIIus. Eyn mobrawn sammet ornat, crux pretexta aurea (...). XXIXus. Eyn kamchen ornat, der bodem grün, doryn weisse fögil, iczlicher in seynem weissen streffechten geheuse. Crux rot mit golde gepfeffert (...). Item quinque casule [dominicales] vna vom brawnen sammet cum paruula cruce pretexta (...). Dy andir eyn belke, der grunt lichtblo, doryn bildwerg swarcz bömecht, blumwerg mit golden hunden. Crux pretexta aurea (...). Dy dritte eyn belke, der bodem rot, ibi blo bildwerg mit weissen facien vnd blo bömecht vnd tirley sine cruce (...) Dy virde eyn bloe kamche, doryn groe geeckte rozen gesaczt, sam in quadritur spiczgeeckt geheusicht. Crux simplex pretexta aurea (...) Dy vőnfte von bloem alden atlas, das creucze pretexta aurea serico intermixto, obducta alia parua pretextula (...). Item IIIIor casule pro requiem. Item vnus ornatus rubeus cum floribus aureis; utuntur eo in passione Domini super Crucifixo". - Najdawniejsze inwentarze..., s. 15-19).

${ }^{52}$ Wykaz posiadanych w roku 1452 przez kościól Panny Marii paramentów liturgicznych zamieszczają: Najdowniejsze inwentarze..., s. 15-20; natomiast listę ksiażek - tamże, s. 23-28. 
Następny spis przedmiotów i paramentów liturgicznych przeprowadzili w roku 1467: Jan Gartner, Jan Wersing [Wierzynek], Jan Karnkowski, Paweł Newburger [Neubirger, Nayburger], Marcin Hower i Mikołaj Zalcz oraz zakrystian Jan (Luce) i wicezakrystian Piotr. Zapisali wówczas w inwentarzu dwadzieścia trzy pozłacane kielichy i cztery srebrne z pozłacanymi czarami, oraz hermowy („caput”) relikwiarz z relikwiami Jedenastu Tysięcy Dziewic. Kolejne trzy pozłacane kielichy znajdowały się w posiadaniu magistra Michała, Jana Luce (zakrystiana) oraz polskiego kaznodziei w kościele Mariackim, u którego był także kielich z pateną ofiarowany do kościoła przez księdza Stano (Stefana) Leipnigera. W tymże roku (1467) sprawiono jeszcze trzy nowe ornaty $\mathrm{z}$ humerałami (dwa $\mathrm{z}$ daru Hyncze [Hinczy $\mathrm{z}$ Rogowa], jeden zaś niejakiej Myotkowej) oraz jeden bez humerału (dar Borneisyn [Borneisza]), jedno palium (sumptem pana Hyncze [Hinczy z Rogowa]) i dwie kapy (z daru Zabkynne [Zepkinowej] i Dittrichyn [Ditricha]) ${ }^{53}$.

Kolejne dary złożone do zakrystii odnotowano dwa lata później (1469), kiedy to Jan Wedirheym przekazal na ręce Pawła Beera dwa ornaty, w tym jeden $\mathrm{z}$ humerałem; następny ornat $\mathrm{z}$ humerałem ofiarował Jan von Tegil ${ }^{54}$. Z kolei w roku 1470 niejaka Brosilin z Olkusza dała do kościoła kwiecisty ornat ze złotym krzyżem oraz humerał, a Urszula Feyfrytynne [Feifritowa]) ofiarowała mszał oraz ornat $\mathrm{z}$ humerałem. W tymże samym roku (1470) wyliczono również w inwentarzu dwadzieścia pozłacanych kielichów i cztery srebrne, przy czym pięć innych kielichów było wypożyczonych i znajdowały się: u proboszcza Jerzego Szwarca (mały, pozłacany), Krystyna (sprawiony przez księdza Stefana Lepingera [Leipnigera]), doktora Michała (srebrny), Jana Luce, Jana zakrystiana; również jeden ornat posiadał pan „Hinczonis” [Hincza z Rogowa], a trzy kapy były u Bartłomieja Borneisza, Dittricha i zakrystiana ${ }^{55}$. Natomiast dwa lata później (1472) rajcy krakowscy sprawili także do kościoła krzyż (zapewne ołtarzowy) ozdobiony perłami, a zakrystian Jan dał dwie małe, srebrne ampułki. Zwiększył się również o sześć następnych stan ilościowy ornatów, które ofiarowali m.in.: czerwony $\mathrm{z}$ humerałem - Weis Closynne [Kloszowa], $\mathrm{z}$ zielonego aksamitu $\mathrm{z}$ humerałem - Jan von Tigil [Tegil] senior, $\mathrm{z}$ adamaszku - Wersing [Wierzynek] (Jan), $\mathrm{z}$ czerwonej kamchy - magister Paweł, proboszcz z Proszowic; przybyły też dwa humerały: jeden $-\mathrm{z}$ przedstawieniami śś. Apolonii, Doroty, Katarzyny i NMP, oraz drugi - z przedstawieniami śś. Barbary, Katarzyny i NPM, a także jedna kapa zapisana legatem zmarłego Climka [Klimka] (oddana na ręce Jana Karnkowskiego) ${ }^{56}$. Jeszcze w roku 1473 Mikołaj Gobil darował kolejny już ornat z czerwonego aksamitu,

\footnotetext{
${ }^{53}$ Tamże, s. 42 i ns.

${ }^{54}$ Tamże, s. 41, gdzie również odnotowano, iż humerał ofiarowany przez Jana von Tegil zdobily trzy przedstawienia oraz perły i cztery hiacynty.

${ }^{55}$ Najdawniejsze inwentarze..., s. 41 i ns.

${ }^{56}$ Tamże, s. 21, 38, 40-41. Wydaje się, iż stosunkowo bogato prezentował się ornat sprawiony przez Jana von Tigil [Tegil] seniora, który w inwentarzu opisano: „casulam de examitto viridi cum floribus, cum cruce aurea, in cuius finbrijs et dyademate sunt lapides de testis margaritarum et ymago est Saluator, subtus est clenodium trium leonum aureorum in campo flaueo". - Tamże, s. 40.
} 
z albą i humerałem, a podzakrystian Marcin przyjął srebrny kielich (z pozłacaną w środku czara) ze srebrną pateną ozdobioną pozłacanym krzyżem. Z kolei w roku 1474 Hincza z Rogowa ofiarował do kościoła żółty aksamitny ornat z krzyżem oraz albę i humerał, Urszula Mozanczynne [Mozanczowa] dała zaś srebrny, pozłacany kielich $z$ napisem: MARIA oraz ornat i albę ${ }^{57}$. Rok później (1475) egzekutorzy testamentu Macieja Opoczki (z 1473) przekazali pozłacany kielich z kolistym nodusem, ozdobiony napisem: HIC CALIX COMPARATUS EST PER DOMINUM MATHIAM OPOCZKO PRO ECCLESIA BEATE VIRGINIS oraz patenę, przeznaczając je do ołtarza znajdującego się „in medio ecclesie Passionis Domini" ${ }^{\text {"58. W }}$ W następnym roku (1476) Jan Luce darował pacyfikał z relikwiami: „SS. Otilie, Nicolai, Clementis, Stanislai, Andreae et Elizabet”, w którego środku znajdowała się relikwia Krzyża Świętego, oraz humerał. Maciej Brenner zaś legował zapis m.in. na wykonanie srebrnego kielicha do przechowywania relikwii Krzyża Świętego; w tymże roku (1476) Mikołaj Thawchir z Nysy, doktor dekretów, przekazał kolejne książki do biblioteki ${ }^{59}$.

Dzięki tej sporej ilości odnotowanych w ostatnim czasie darów do zakrystii kościoła Panny Marii, spisujący jeszcze w roku 1476 inwentarz przedmiotów liturgicznych danych za urzędowania zakrystiana Jana, panowie: Jakub Wilkowski, Jan Wersing [Wierzynek], Jan Karnkowski, Marcin Bełze [Bełza], Walter Kesinger [Kisling, Jan Waltek] i Paweł Neubirger [Nayburger, Newburger] zapisali aż dwadzieścia trzy pozłacane kielichy i pięć srebrnych z patenami, oraz trzy pozłacane kielichy wypożyczone altarystom: do kaplicy Św. Stanisława, do kaplicy (kościoła) Św. Wojciecha oraz kaznodziei polskiemu w kościele Mariackim. Osobno zanotowano dar (z tegoż zapewne roku 1476) Jana Odow, którym był pozłacany kielich ozdobiony rubinami i napisem: HUNC CALICEM COMPARAUIT IOHANNES ODOW, wraz z pozłacaną pateną. Natomiast wśród paramentów liturgicznych przekazanych na ręce zakrystiana Jana odnotowano jedno aksamitne (czerwone i haftowane złotem) antependium, sprawione przez Bartłomieja Reycha [Reicha] i Jakuba Swedniczara [Sweydniczera], oraz dwie kapy, z których jedną dał Jan Czarny, a druga Katarzyna Zepkynna [Zepkinowa] $]^{60}$.

Następny dar do kościoła zapisano w księgach w roku 1479, kiedy to sprawiono, sumptem Doroty, siostry Jana Luce, kielich „deauratum in toto, in cuius pede sunt quasi flores ascendentes sursum versus nodum, qui nodus est quasi tibarium vnum", wraz z pateną. Rok później (1480) oddał też Mikołaj Leyniter odnowiony, pozłacany kielich $\mathrm{z}$ napisem: AVE VERUM CORPUS

${ }^{57}$ Tamże, s. 38-39.

58 Zapis testamentu Macieja Opoczki zamieszcza CA I, nr 614. Dar w postaci kielicha i pateny, do ołtarza Męki Pańskiej odnotowano w inwentarzu. - Najdawniejsze inwentarze..., s. 39.

${ }^{59}$ Zapis testamentu Macieja Brennera zawiera CA I, nr 649. Natomiast oddany przez Jana Luce pacyfikał oraz humerał (ozdobiony przedstawieniami świętych: Stanisława, Wacława i Floriana oraz kamieniami: kryształami, turkusami i perłami), a także listę ksiąg ofiarowanych przez Mikołaja Thawchir z Nysy podal Franciszek Pi e k os ińs k i [w:] Najdowniejsze inwentarze..., s. 39-40.

${ }^{60}$ Tamże, s. 30-31. 
CHRISTI, QUOD IN CRUCE PEPENDIT, oraz patenę (wykonane jeszcze w roku 1447$)^{61}$. Z kolei w roku 1481 Hannus Gobil przekazal kielich oraz ornat $\mathrm{z}$ humerałem ${ }^{62}$, a dwa lata później (1482) Marcin Burghard z Bochni, altarysta ołtarza ŚŚ. Piotra i Pawła Apostołów w kościele Mariackim, legował zapisem testamentowym odnowiony, pozłacany kielich, monstrancje relikwiarzową i dwie srebrne, pozłacane ampułki, do wspomnianego zaś ołtarza - dwa ornaty $\mathrm{z}$ humerałami oraz adamaszkowe antependium. Jeszcze $\mathrm{w}$ tym samym roku (1482) darował srebrną puszkę na krzyżmo święte Grzegorz z Sącza, altarysta ołtarza Św. Marii Magdaleny ${ }^{63}$, w roku zaś 1484, przy objęciu urzędu zakrystiana przez Jana Zepka, oddano na przerobienie dwa relikwiarze, z których to przedmiotów wykonano mała, pozłacaną monstrancję ${ }^{64}$.

Przekazanie do kościoła Mariackiego nowych przedmiotów i paramentów liturgicznych odnotowano też w roku 1487, kiedy to Małgorzata Scholwiczowa sprawiła pozłacany kielich $\mathrm{z}$ patena, dwie srebrne, pozłacane ampułki oraz ornat $\mathrm{z}$ humerałem, a Stanisław Dolsky [Dolski] oddał w imieniu Mikołaja Dolskyego [Dolskiego] czerwony ornat $\mathrm{z}$ humerałem, stułą i manipularzem, do kaplicy zaś Małgorzaty Scholwiczowej - drugi ornat, również z wszystkimi „,dodatkami”, oraz antependium do ołtarza ${ }^{65}$. Rok później (1488) egzekutorzy testamentu Piotra ze Skawiny ofiarowali do kościoła kolejny już pozłacany kielich wraz z pateną oraz krzyż (zapewne ołtarzowy) z relikwiami i humeral ${ }^{66}$. Natomiast w roku 1490 inni egzekutorzy testamentu, tym razem

${ }^{61}$ Przy okazji oddania kielicha opisano go dosyć dokładnie. Na podstawie odnośnego tekstu dowiadujemy się, iż na czaszy kielicha znajdował się biegnący naokoło napis „«Aue verum corpus Christi, quod in cruce pependi», et in medio in nodo sunt "pockli" et in quolibet est vna litera de «Ihesus». In pede vero inferiori sunt ymagines, primo passio in cruce cum Iohanne et Maria in utrisque partibus, sancta Katherina, Thesus in sepulcro cum virga et flagello et Maria ex vno latere et Paulus cum gladio. In inferiori circulo set scriptum: «Hunc calicem comparauit magister Nicolaus Leyniter anno Domini MCCCCXLVII». In patena vero est Voreonica exculpta". - Najdawniejsze inwentarze..., s. 32-33).

${ }^{62}$ Oddany przez Hannusa Gobila ornat wykonany był $\mathrm{z}$ aksamitu, natomiast humeral zdobiony perłami. - CA I, $\mathrm{nr} 800$.

${ }^{63}$ Najdawniejsze inwentarze..., s. 33-34.

${ }^{64}$ Tamże, s. 31-32.

${ }^{65}$ Tamże, s. 34, 37. Na ofiarowanym przez Małgorzatę Scholwiczową kielichu znajdowała się na stopie plakietka „Misericordie, quam duo angeli tenent distorte, nodus est in medio cum turriculis, superius est corona, in summitate sunt tanquam glandes. In patena est Ihesus in sepulcro cum Maria, laboris grossi, cum huiusmodi signo". - Tamże, s. 34 .

${ }^{66}$ Zapis inwentarzowy przekazał nam informację o wyglądzie zarówno kielicha, jak i krzyża ołtarzowego, odnotowanych jako: „Calicem (...) in cuius pede sunt flores alias gewegse sursum ascendentes versus calicem et nodum habet in medio sexangularem cum turriculis grossis; in quolibet angulo siue quadrato sunt due fenestre, superius in grano calicis est corona, sub qua est scriptura: «Anno Domini MCCCC LXV per me Iohannem sacristianum»; patena habet crucem (...). Item crux fuit talis: superius habet quinque vitra quadrangula, sub quibus omnibus sunt reliquie et sunt VIII cornua, in quolibet est vnus lapis brunatici coloris et margarite circa vnumquemque. Ex alia autem parte sunt ymagines insculpte: superius Katherina, in medio beata Virgo cum puero, ex vna parte Barbara, ex alia Dorothea, inferius Margareta; habet pedem ad altitudinem vnius palme cum floribus et turriculis in medio". - Najdawniejsze inwentarze..., s. 34-35. 
wicezakrystiana Marcina, przekazali następny pozłacany kielich z pateną i pozlacany krzyż ${ }^{67}$.

W roku 1494 zwiększeniu uległa także ilość ksiag, przechowywanych w bibliotece, o woluminy ofiarowane przez Piotra Salomona oraz oddany trzy lata później (1497) przez Jakuba Webera z Krakowa - mszal ${ }^{68}$. Jednym $\mathrm{z}$ ostatnich już XV-wiecznych darów do krakowskiej fary był przekazany w roku 1498 przez Piotra z Kurozwęk, kasztelana sandomierskiego, pozłacany kielich, którego stopę ozdabiał odciśnięty herb Rosa, wraz pateną ${ }^{69}$. Natomiast jeszcze w roku 1500 oddano, uprzednio legowany przez Łazarza „Messersmida", pozłacany kielich z napisem: HUNC CALICEM COMPARAUIT LASARUS WEINSCHENK, ANNO 1476, oraz trzy ornaty (ofiarowane przez Lithwanusa, Mentlera, Mikołaja Baszgerta), humerał (dany przez Mikołaja Baszgerta), dwie tuniki (z daru Tomasza Glasera) i kape (oddane przez zakrystiana Jana i Katarzynę Zepczinę) $)^{70}$.

Jak zatem można wnioskować z przedstawionego powyżej stanu wyposażenia w przedmioty i paramenty liturgiczne XV-wiecznej zakrystii kościoła Mariackiego było ono w owym stuleciu nieustannie powiększane, a $\mathrm{z}$ końcem wieku tworzyło już spory zasób. Część jednak z tych przedmiotów wymienionych przez inwentarze, nie znajdowała się stale w kościele, lecz była niejako wypożyczona dla altarystów. I tak z końcem XV wieku powróciły do rąk zakrystiana kościoła Panny Marii: kielich, dwa ornaty i ,unum crinale cum iammnis decorata", obraz z różnymi relikwiami oraz mszal - oddane przez panią Trewthelyn; puszka na hostię zdobiona różnymi kamieniami - zwrócona przez pana Gamratha; cztery ornaty - oddane przez Jana z Opola, wdowę po Piotrze Kronchyn, Schorenbrantha [Schorembranta], Mikołaja Cinadianusa(?); ornat legowany przez Littoldusa [Linttoldusa, Linttholdusa, Lidentolde] i dwa nowe psałterze legowane zapisem pana Hieronima. Prócz powyższych zwrotów odnotowano również inne (wypożyczone w ciaggu 2. połowy XV wieku), w postaci kielichów, ornatów i ksiąg ${ }^{71}$.

${ }^{67}$ Sprawiony kielich miał sześcioboczny nodus, na którego bokach znajdowały się litery IHESUS, stope zaś ozdabiała plakietka z przedstawieniem Najświętszej Panny Marii. Znacznie bogatszy wydawał się jednak być krzyż ozdobiony ośmioma kamieniami, „quasi zeferis et smaragdis vitreis, in medio berilla eleuata, in alia parte passio, in cornibus sunt quatuor euangeliste, sed habet ligneum pedem"-Najdawniejsze inwentarze..., s. 35.

${ }^{68}$ Tamże, s. 36, 37.

${ }^{69}$ Tamże, s. 37.

${ }^{70}$ Tamże, s. 36-37.

${ }^{71}$ Wypożyczone z kościoła Mariackiego przedmioty oraz paramenty liturgiczne posiadali czasowo: magister Creslaus (pozłacany kielich i ornat), magister Jakub (pozłacany kielich i ornat), Jan Linttoldus [Linttholdus, Littoldus, Lidentolde] (pozłacany kielich), Wlodko (srebrny kielich i ornat, pozłacany kielich Geyslareyna [Geislara, Geislera] i ornat, pozlacany kielich i ornat), Jan z Opola (srebrny kielich i ornat), Mateusz Longus (srebrny kielich i ornat, pozłacany kielich i ornat), Mikołaj Volawia (srebrny kielich, puszkę na wiatyk i obrus), magister Wilhelm (pozlacany kielich Geyslaryna [Geislara, Geislera] i ornat), magister Golbarg [Colbarg, Gothbarg, Goltberg Mikołaj] (księgę obrzędów pogrzebowych, mały mszał, księgę Wilhelma Paryskiego), Jan Czaterveng (jedną księgę), magister Spiliensis(?) (graduał), dzwonnik Mikołaj (pozłacany kielich i ornat), Mateusz kaznodzieja polski (srebrny kielich i ornat, pozłacany kielich, ornat, „Agnus Dei"), magister Vitlich (pozłacany kielich), Polnar [Polner Mikołaj] (ornat), 
Przedstawione niewątpliwie bogate wyposażenie w przedmioty i paramenty liturgiczne zakrystii kościoła Panny Marii, ukazane na podstawie zachowanych XIV- i XV-wiecznych archiwaliów, było wyrazem szczególnym troski, jaką mieszkańcy średniowiecznego Krakowa otaczali „swoja” świąty. nię. Wyraziła się ona również w dbałości o godne mieszczańskiej fary wyposażenie wnętrza, dzięki czemu też w okresie średniowiecza krakowska fara mogła poszczycić się znaczną już ilością ołtarzy ${ }^{72}$, wśród których niewątpliwie najbardziej okazale prezentował się ołtarz główny - sprawiony wspólnymi wysiłkami finansowymi krakowskich mieszczan i mieszkańców Krakowa wykonany w latach $1477-1489$ przez Wita Stwosza ${ }^{73}$. Autorstwa tegoż snycerza były jeszcze dwie tryptykowe nastawy ołtarzy bocznych z początku lat dziewięćdziesiatych XV wieku oraz Krucyfiks umieszczony w ołtarzu Św. Krzyża (1492-1496). Kolejne dwa ołtarze boczne znajdowały się w pobliżu ołtarza głównego, w części prezbiterialnej (ustawione przy północnej i południowej ścianie): Bożego Ciała i Św. Longina (1380), Ofiarowania NMP (3. ćw. XIV w.). Inne wypełniały niejako w całości wnętrze korpusu nawowego, będąc umieszczonymi zarówno po obu stronach tęczy: 10.000 Żołnierzy Męczenników (przed 1397) oraz Zwiastowania NMP (przed 1446), jak i przy zamknięciu naw bocznych: Św. Katarzyny (ok. 1400), Św. Krzyża (przed 1439), oraz przy rozdzielających je filarach (w tym po dwa (?) przy środkowych filarach naw): Trzech Króli (przed 1400) i Św. Trójcy (ok. 1493), Św. Marii Magdaleny (przed 1419) oraz Męki Pańskiej i św. Anny (ok. 1475), ŚŚ. Szymona i Judy Apostołów (przed 1425), Św. Anny (przed 1437), Wniebowzięcia NMP (przed 1442), Św. Leonarda (przed 1460). Następne oftarze znajdowały się w nawach bocznych, pomiędzy wejściami do dobudowanych do korpusu nawowego kaplic i krucht: ŚŚ. Antoniego i Doroty (1393), ŚŚ. Piotra i Pawła Apostołów (przed 1396), Św. Tomasza (przed 1430), Nawiedzenia NMP (ok. 1432), Św. Agnieszki (przed 1444), Św. Benedykta (przed 1460); kolejne zaś ozdabiały wnętrza tychże kaplic: Zwiastowania NMP (ok. 1433), Matki Bożej Śnieżnej (ok. 1435), Przemienienia Pańskiego (ok. 1435), Męki Pańskiej (ok. 1435), Bożego Ciała (ok. 1439-1441), Św. Trójcy (ok. 1441), Św. Michała (ok. 1443), Wszechmogącego Boga i Narodzenia NMP (1445). Jeszcze inne cztery ołtarze znajdowały się w kaplicach wieżowych (w tym dwa w kaplicy Św. Aleksego): Św. Aleksego (przed 1383) i Wniebowzięcia NMP (z k. XV lub pocz. XVI w.), ŚŚ. Stanisława i Wacława (przed 1383) oraz - w kaplicy Brackiej - Wszechmogącego Boga i Nawiedzenia NMP (ok. 1395). Z końcem XV stulecia zatem, mieszczanie krakowscy mogli już uczestniczyć w nabo-

Jan ze Skawiny (pozłacany kielich i ornat), Mikołaj Langzedel (ornat), Cipser [Czipser, Czypser Mikołaj] (ornat), Andrzej z Biecza (srebrny kielich i ornat) - zob. Najdawniejsze inwentarze..., S. $44-45$.

${ }^{72} \mathrm{Na}$ temat średniowiecznych ołtarzy w kościele Panny Marii. - E. P i w o w a r c z y k, Dzieje..., s. 124, 131-132, 134-160.

${ }^{73}$ Tamże, s. 150-157. 
żeństwach sprawowanych aż przy trzydziestu dwóch (pomijając ołtarz główny) ołtarzach bocznych, bądź kaplicowych, w tym przy trzech mających nowe nastawy. Była to stosunkowo duża liczba ołtarzy zdobiących wnętrze średniowiecznej świątyni, a uwzględniając fakt istnienia przy nich altarii oraz przy niektórych więcej niż jednym ministerium, z pewnością w mariackiej farze trwała prawie nieustannie służba Boża ${ }^{74}$.

Sprawowanym w kościele Mariackim nabożeństwom towarzyszyła również - zapewne już od końca XIV stulecia - muzyka organowa, których to instrumentów pod koniec XV wieku były w kościele dwa duże i co najmniej jeden pozytyw, grających w czasie wielkich celebracji razem. Również donośny musiał być dźwięk wydobywający się (gdy używano ich razem) z odlanych w ciągu omawianych stuleci czterech dzwonów: datowanego na przełom XIII/XIV w., „Tenebrata” i „Misjonała” (1386-1390), oraz „Półzygmunta” (1438). Natomiast do sprawowania świętych obrzędów służyły: XIV-wieczna chrzcielnica i dwie cynowe (?) kropielnice (z pocz. XIV w.) oraz wszelkie potrzebne przedmioty i paramenty liturgiczne, wraz $z$ odpowiednimi księgami, przechowywanymi w zakrystii kościoła i w Mariackiej bibliotece ${ }^{75}$.

Zdecydowana większość ze wspomnianego wyposażenia wnętrza średniowiecznego kościoła Panny Marii, razem z odczytanym na podstawie zapisów inwentarzy wyposażeniem zakrystii - pomimo formalnego sprawowania w ciagu XIII i XIV patronatu przez biskupa krakowskiego, a od roku 1415 przez króla polskiego - pochodziła z pobożnościowo-wotywnych fundacji mieszczan krakowskich i rady miejskiej; również z ich zapisów utrzymywane były przy ołtarzach istniejące i tworzone nowe ministeria. Dzięki temu też, w okresie średniowiecza dzieje krakowskiej fary nierozerwalnie złączyły się $\mathrm{z}$ mieszczaństwem, a posiadanie przez zamożny patrycjat swoich kaplic w tej świątyni oraz zezwolenie na pochówek w jej wnętrzu osób szczególnie zasłużonych dla kościoła umocniły jeszcze tę pozycję, ugruntowaną w następnym stuleciu.

${ }^{74}$ Nieustającą Służbę Boża, niejako na wzór trwającej w katedrze wawelskicj, sprawowali zarówno posługujący w kościele wikarzy, jak i altaryści, czy tworzący własne korporacje gracjaliści, psałterzyści, mansjonarze. Szerzej na temat wspomnianych korporacji. - E. P i wo w a r z y k, Dzieje..., s. 122-123, 183-184.

${ }^{75} \mathrm{O}$ wyposażeniu wnętrza średniowiecznego kościoła Panny Marii na podstawie zachowanych archiwaliów oraz przetrwałych zabytków sztuki. - E. P i w ow a r c z y k, Dzieje..., s. 121-182. 